\title{
Improving Employee Satisfaction Through Organization Support
}

\author{
Hilya Shiffa, Tiarapuspa, Sarfilianty Anggiani* \\ Faculty of Economics and Business \\ University of Trisakti \\ Jakarta, Indonesia \\ *shiffahilya@yahoo.com
}

\begin{abstract}
This study aims to identify and analyze the effect of health protection benefits, recreation leave, and flexible working hours on job satisfaction in employees of PT. Pos Indonesia, South Jakarta branch. Retrieval of data is done through the deployment of a questionnaire to 109 employees PT. Pos Indonesia branch of South Jakarta with scale Likert 1-5 was then analyzed by SEM (Structural Equation Modeling). Research shows that only two hypotheses in this study were accepted, namely, there is an influence between recreation leave and flexible working hours on job satisfaction.
\end{abstract}

Keywords - benefit health protection, flexible working hour, job satisfaction, recreation leave

\section{INTRODUCTION}

Terms Indonesia 4.0 certainly has been no stranger anymore for us. Early beginning of the term this is the revolution of the industry in the whole world, which is a revolution of the industrial fourth. It can be said as a revolution, because the changes that occur have a profound effect on the world's ecosystems and ways of life. Revolution Industrial 4.0 even believed could improve the economy and quality of life is significant with this 4.0 also can improve job satisfaction a person in work.

PT. Pos Indonesia is one of the company's state-owned enterprises engaged in the field of services of the service delivery of goods, money, documents, and activities of services other who tried to meet the needs of consumers in general. At present, the Pos Indonesia business entity form is a limited liability company and is often referred to as PT. Pos Indonesia. Optimization of responsibility of companies in the face of the demands of the development of the times to encourage companies to consider it a mature quality source of power human. Management sources power humans are good also creates a tendency that both will increase the satisfaction of the work of employees in personal as well as a whole.

Employees are assets of the company which is very valuable and must be managed by both by the company to give a contribution which is the maximum. One of the things that must be a concern of the company is the job satisfaction of its employees. Satisfaction work is the attitude of public employees to work. When an employee feels satisfaction in working, he will strive as much as possible to put out the whole ability on the responsibility that is given by the company.

\section{LITERATURE REVIEW}

According to Robbins defines satisfaction of working as feeling positive on a job, which is the impact/outcome evaluation of various aspects of the job such [1]. Satisfaction work is an assessment and the attitude of a person or employee to work and relate with the environment of work, type of work, the relationship between friends work, and the relationship of social at the place of work. In simple satisfaction of work or job satisfaction can be summed up as anything that makes a person enjoys the work that is done because they feel happy in doing her job. The level of satisfaction of the work of employees in a company is key to the spirit that supports the realization of the purpose of the company. One of the factors that influence the satisfaction of the work of employees can be seen from the provision of benefits satisfaction of health, employees are given the benefit of protection of health will be satisfied, even many workers are healthier more productive it against his company. According to Karion et al., benefits have become the most important and consistent element in employee benefits [2]. Based on these arguments, this study hypothesizes that the benefits of health benefits (Benefit Health Protection) increase employee satisfaction of PT. Pos Indonesia South Jakarta branch.

Another factor that can affect job satisfaction of PT. Pos Indonesia employees in the South Jakarta branch is by giving the employee time off. According to Naithani leave annual is the time of hours of work or be called a holiday. Leave has several benefits in working life [3]. Improving the anxiety and stress of employees, increase the fatigue of employees are low, and mental employees, leave can restore the mind of employees into fresh [4]. Other work-life balance opportunities for employees are sick leave, work pressure can create anxiety, stress, and illness that can make employees sick. Employees are sick are not able to focus and concentration on the job because of the discomfort that comes from his illness. Research that is done by Gatchel et al., showed that the employees were 
given the facility off sick by companies tend to quickly recover from an illness compared to companies that don't provide health benefits [5]. However, according to Casper et al., states that companies that offer sick leave tend to have advantages compared to companies or competitors who are reluctant to provide sick leave [6]. Employee performance that is focused, synergized, and foremost makes provisions for employee welfare through facilities such as sick leave [7]. Base on that arguments, this study hypothesizes that leave (Recreation Leave) increases the satisfaction of employees PT. Pos Indonesia branch of South Jakarta.

Furthermore, factor that affect the satisfaction of the work of employees in PT. Pos Indonesia branch of South Jakarta is the hours of work are flexible. Workers are motivated because they have the flexibility to determine work time. Working flexibly covers the flexibility of scheduling, location, and duration of work. Research previously conducted on setting hours of work are flexible has been observed impact positively on the satisfaction of work and schedule of work. According to Jansen have an increase in access to hours of work is flexible not only beneficial for the employees with the sole responsibility of the family, but for all the employees that work [8]. Studies have hypothesized that the hours of work that feasible (Flexible Working Hours) increase the satisfaction of employees PT. Pos Indonesia branch of South Jakarta.

\section{METHODS}

This research refers to research that has been done by Nisar [9]. The design of this study examines the effect of health protection benefits, vacation leave, and flexible working hours on job satisfaction.

The dependent variable (job satisfaction) and the independent variable (health protection benefits, vacation leave, and flexible working hours) in this study were measured on a 5 - point Likert scale. $1=$ Very not agree, 2 = Do not agree, $3=$ Quite agree, $4=$ agree, $5=$ Very agree.

Data obtained using a structured questionnaire. The total sample minimum in research is of 100 respondents, by using a formula indicator multiplied by 5. A total of 109 respondents who be sampled individuals al, employees of Pos Indonesia branch of South Jakarta.

\section{RESULTS AND DISCUSSION}

TABLE I. RESULTS OF TEST VALIDITY AND RELIABILITAS

\begin{tabular}{|c|c|c|c|c|}
\hline No & Statement Items & p-value & Cronbach's Alpha & Decision \\
\hline \multicolumn{5}{|c|}{ Benefit Health Protection Variable } \\
\hline 1 & Incentives not a form of money that is most in demand is the protection of health. &, 732 & \multirow[t]{4}{*}{, 497} & \multirow{4}{*}{$\begin{array}{l}\text { Not Valid } \\
\text { and Not } \\
\text { Reliable }\end{array}$} \\
\hline 2 & I am satisfied with the benefits of health were given. & , 461 & & \\
\hline 3 & The satisfaction of work increases if I was given the insurance health is adequate. &, 763 & & \\
\hline 4 & $\begin{array}{l}\text { The benefits of protection of health are more important than the benefits of monetary or } \\
\text { non- monetary others. }\end{array}$ &, 529 & & \\
\hline \multicolumn{5}{|c|}{ Recreation Leave Variable } \\
\hline 1 & I get annual leave to spend with family. &, 619 & \multirow[t]{6}{*}{, 813} & \multirow{6}{*}{$\begin{array}{l}\text { Valid } \\
\text { and } \\
\text { Reliabel }\end{array}$} \\
\hline 2 & The company provides annual leave so that employee performance increases. &, 736 & & \\
\hline 3 & I feel satisfied getting annual leave from superiors compared to those who don't. &, 712 & & \\
\hline 4 & $\begin{array}{l}\text { I'm more like work at the company } \\
\text { that provide leave pregnant. }\end{array}$ &, 716 & & \\
\hline 5 & Pregnant leave makes female employees less worried about their responsibilities at home &, 783 & & \\
\hline 6 & Leaves were given impacting positively on the satisfaction of the work of employees. &, 777 & & \\
\hline \multicolumn{5}{|c|}{ Flexible Working Hour Variable } \\
\hline 1 & $\begin{array}{l}\text { I really helped with setting a plan of work are flexible ( Example ; Free determine time } \\
\text { start and time stops working ). }\end{array}$ &, 750 & \multirow[t]{3}{*}{, 773} & \multirow{3}{*}{$\begin{array}{l}\text { Valid } \\
\text { and } \\
\text { Reliabel }\end{array}$} \\
\hline 2 & $\begin{array}{l}\text { Organizations can observe the emergence of satisfaction working employees with their } \\
\text { setting hours of work are flexible. }\end{array}$ & , 901 & & \\
\hline 3 & $\begin{array}{l}\text { Employees whose potential can be maintained when companies provide time work are } \\
\text { flexible. }\end{array}$ &, 850 & & \\
\hline \multicolumn{5}{|c|}{ Job Satisfaction Variable } \\
\hline 1 & I would recommend a job at this organization to a friend. &, 636 & \multirow[t]{4}{*}{, 683} & \multirow{4}{*}{$\begin{array}{l}\text { Valid } \\
\text { and } \\
\text { Reliable }\end{array}$} \\
\hline 2 & I rarely think about finding a job at another company. &, 770 & & \\
\hline 3 & $\begin{array}{l}\text { Companies me very flexible and appreciate the responsibilities responsible employee of } \\
\text { the family. }\end{array}$ &, 785 & & \\
\hline 4 & $\begin{array}{l}\text { Allowances and facilities are granted by the company highly enough for me and the } \\
\text { family. }\end{array}$ &, 677 & & \\
\hline
\end{tabular}

Methods of analysis of the data in the study of this are structural equation sampling (SEM) was used to analyze the relationship or influence variable independent of the variable dependent that nature formed path. In the structural equation, sampling analysis program used is Amos. 
TABLE II. Model FeasibILITY TEST Results

\begin{tabular}{|c|c|l|l|}
\hline $\begin{array}{c}\text { Goodness of fit } \\
\text { index }\end{array}$ & $\begin{array}{c}\text { Criteria (cut-off } \\
\text { value) }\end{array}$ & $\begin{array}{c}\text { Indicator } \\
\text { Value }\end{array}$ & Conclusion \\
\hline Chi-Square $\left(\boldsymbol{X}^{2}\right)$ & Approaching 0 & 131,808 & Poor of Fits \\
\hline Probability & 0.05 & 0.000 & Poor of Fits \\
\hline NFI & 0.90 & 0,747 & $\begin{array}{l}\text { Marginal of } \\
\text { Fits }\end{array}$ \\
\hline TLI & 0.90 & 0,902 & Good of Fits \\
\hline
\end{tabular}

\section{A. Test Validity and Reliability}

This study aims to determine the effect of health protection benefits, recreation leave, and flexible working hours on job satisfaction. Table 2 is a table of the results of the goodness of fits test where this test is performed to determine whether the data used is under the model. By thus, conclusions were obtained are models of the good of fits with measurements CMIN, NFI, TLI, CFI, and RMSEA. Thus, the model can be used to test theoretical hypotheses.

In the study 's multiple regression analysis was used to analyze each. Generate data as follows:

- Benefit health protection, does not affect significantly (H1 Rejected)

- Recreation leave, an effect significantly (H2 Accepted)

- Flexible working hour, an effect significantly (H3 Accepted)

Based on the results of the testing hypothesis to benefit health protection does not affect it significantly to job satisfaction in employees PT. Pos Indonesia branch of South Jakarta. The first hypothesis testing results show there is a negative influence of the variable health protection benefits on job satisfaction, meaning that the employees of PT. Pos Indonesia South Jakarta branch does not receive health protection benefits in their work so it does not affect job satisfaction.

Based on the results of testing hypotheses for recreation leave influence significantly job satisfaction in employees PT. Pos Indonesia branch of South Jakarta, obtained the relationship positive between recreation leave to job satisfaction. That is employees who work on PT. Pos Indonesia branch of South Jakarta receives time off work quite that given the company so that things that can affect job satisfaction them.

Based on the results of testing hypotheses for flexible working hours affect significantly to job satisfaction in employees PT. Pos Indonesia branch of South Jakarta, obtained a relationship positive between flexible working hours on job satisfaction. That is, employees who worked at PT Pos Indonesia branch of South Jakarta get hours of work are quite so things that can affect job satisfaction brand a.
The results showed that work motivation positively affects job satisfaction, but job satisfaction surprisingly has no positive and significant effect on organizational commitment. Furthermore, work motivation positively influences organizational commitment [10].

\section{CONCLUSION}

This study provides an overview of the factors that influence job satisfaction. Recreation leave and Flexible working hours have a positive effect on job satisfaction, while health protection benefits hurt job satisfaction. The better it is to get recreation leave and flexible working hours, the employee will be more satisfied with their work

Suggestions for researchers next is to be able to research the company's services in the area outside Jakarta. The study furthermore also be considered to add variable other like Job performance.

\section{REFERENCES}

[1] P.S.A.T. Robbins, Judge, Chemical and Petroleum Engineering Organizational Behavio, vol. 27, 2011.

[2] A. Karion, C. Sweeney, G. Pétron, G. Frost, R. Michael Hardesty, Kofler J, et al. "Methane emissions estimate from airborne measurements over a western United States natural gas field," Geophys Res Lett, vol. 40, no. 16, pp. 4393-7, 2013.

[3] S. Naithani, The Story-Time of the British Empire: Colonial and Postcolonial Folkloristics. Press Mississippi, 2010.

[4] M. Cardone, A. Kandilci, C. Carella, J.A. Nilsson, J.A. Brennan, S Sirma, et al., "The Novel ETS Factor TEL2 Cooperates with Myc in B Lymphomagenesis," Mol Cell Biol., vol. 25, no. 6, pp. 2395-405, 2005.

[5] R.J. Gatchel, I.Z. Schultz and K. King, "Handbook of occupational health and wellness," Handbook of Occupational Health and Wellness, pp. 1-576, 2012.

[6] W.J. Casper, C. Harris, A. Taylor-Bianco and J.H. Wayne, "Workfamily conflict, perceived supervisor support and organizational commitment among Brazilian professionals," J Vocat Behav [Internet]. Vol. 79, no. 3, pp. 640-52, 2017.

[7] J. Sirma, "The relationship between work life balance practises and employee performance: case study of un women esaro," A Res Proj Rep Submitt to Chandaria Sch Bus Partial Fulfillment Requir Degree Exec Masters Empl Dev., 2015.

[8] N. Jansen, D. Mohren, V. Amelsvoort, J. LG and I. Kant, "Changes in working time arrangements over time as a consequence of work-family conflict," Int. Chronobiol., vol. 27, no. 5, pp. 1045-61, 2010.

[9] S. Nisar and D.A. Siddiqui, "A Survey on the Role of Fringe Benefits in Employee Satisfaction - An Analysis of Organizations of Pakistan," Int. J. Hum. Resour. Stud. Vol. 9, no. 1, pp. 232, 2019.

[10] R.S. Murtiningsih and T. Puspa, "Masihkah Job Satisfaction Dan Motivation Memengaruhi Organizational Commitment?,” J. Manaj. dan Pemasar Jasa., vol. 12, no. 1, pp. 147, 2019. 